\begin{tabular}{|l|l|c|}
\hline $\begin{array}{l}\text { 2. To: (Receiving Organization) } \\
\text { Packaging Engineering } \\
(03 E 00)\end{array}$ & $\begin{array}{l}\text { 3. From: coriginating Organization) } \\
\text { Packaging Engineering (03E00) }\end{array}$ & $\begin{array}{l}\text { 4. Related EDT No.: } \\
\text { NA }\end{array}$ \\
\hline $\begin{array}{l}\text { 5. Proj./Prog./Dept./Div.: } \\
\text { D0T-7A Test Program (TG71C) }\end{array}$ & $\begin{array}{l}\text { 6. Design Authority/ Design Agent/Cog. } \\
\text { Engr: A .G. Field/D. L. Kelly }\end{array}$ & $\begin{array}{c}\text { 7. Purchase Order No.: } \\
\text { NA }\end{array}$ \\
\hline
\end{tabular}

\section{Originator Remarks:}

At the time this test $\mathrm{plan}$ was issued for review and approval, the packaging manufacturer had noted there would be a change to the lift lugs, and that the vent filter fitting part number is incorrect on the drawings provided. Also, Appendix C (test data sheets) is not included as these are "blank" forms. Once updated drawing information is received from the sponsor, and information is obtained and added to the test data sheets, this document will be updated and revised via an Engineering Change Notice.

11. Receiver Remarks: 11A. Design Baseline Document? [] Yes [X] No
9. Equip./Component No.:

NA

10. System/Bldg./facility:

NA

12. Major Assm. Dwg. No.:

NA

13. Permit/Permit Application No.: NA

14. Required Response Date: $05 / 27 / 97$

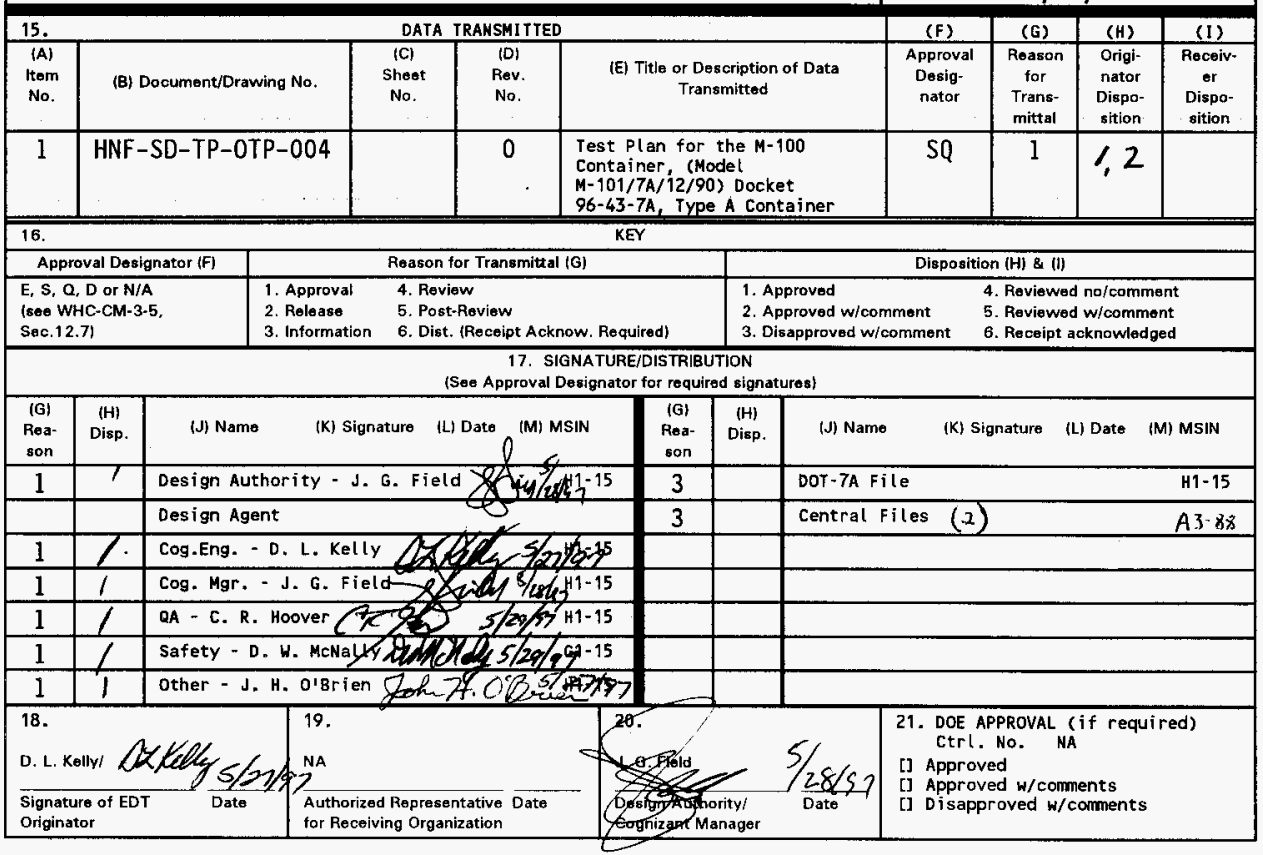




\title{
TEST PLAN FOR THE M-100 CONTAINER, (MODEL M-101/7A/12/90) DOCKET 96-43-7A, TYPE A CONTAINER
}

\author{
D. L. Kelly
}

Rust Federal Services Inc., Northwest Operations, Richland, WA 99352 U.S. Department of Energy Contract DE-AC06-96RL13200

$\begin{array}{lll}\text { EDT/ECN: } & 621082 & \text { UC: } 2020 \\ \text { Org Code: } & 03 E 00 & \text { Charge Code: TG71C } \\ \text { B\&R Code: } & \text { HC1103000 } & \text { Total Pages: } 36\end{array}$

Key Words: Type A Packaging, M-100, Radioactive, M-101/7A/12/90, Docket $96-43-7 \mathrm{~A}$

Abstract: This document describes the test plan for the M-100 Container, Model M-101/7A/12/90. This packaging system is designed to ship Type A solid, radioactive materials, normal form, Form Nos, 1, 2, and 3 . The nominal overall dimensions, including risers, of the $M-100$ Container are $79 \times 54 \times 42$ inches. The capacity of the container is approximately $89.9 \mathrm{ft}^{3}$. The estimated gross weight of the packaging and contents is $90001 \mathrm{~b}$.

TRADEMARK DISCLAIMER. Reference herein to any specific commercial product, process, or service by trade name, trademark, manufacturer, or otherwise, does not necessarily constitute or imply its endorsement, recommendation, or favoring by the United States Government or any agency thereof or its contractors or subcontractors.

Printed in the United States of America. To obtain copies of this document, contact: Document Control Services, P.O. Box 950, Mailstop H6-08, Richland WA 99352, Phone (509) 372-2420;

Fax $(509) 376-4989$.

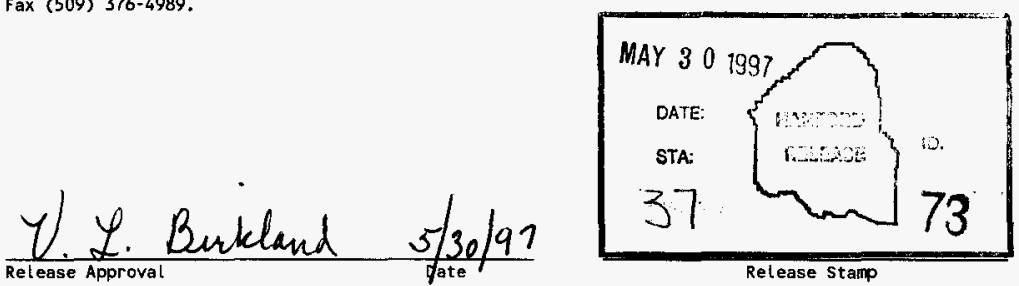

Approved for Public Release 
HNF-SD-TP-0TP-004

Revision 0

TABLE OF CONTENTS

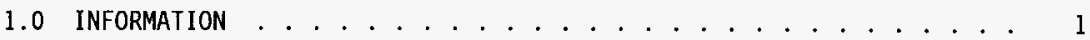

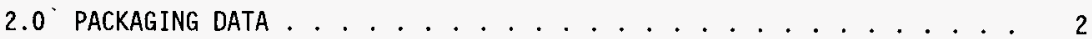

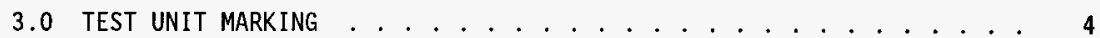

4.0 PRE-LOADING INSPECTIONS ..................... 5

5.0 SIMULATED PAYLOAD ........................ 6

6.0 DESIGN CONFIRMATION SEQUENCE . . ............ . 7

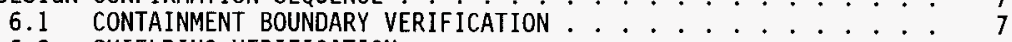

6.2 SHIELDING VERIFICATION ............... 7

7.0 TEST SEQUENCE: TEST UNITS $43-$ TU-01 THROUGH $43-$ TU-07 . . . . . . 7

7.1 ASSEMBLY, LOADING, AND CLOSURE ............. 8

7.2 STACKING TEST . . . . . . . . . . . . . . 9

7.3 DROP TEST $-1.2 \mathrm{~m}(4.0 \mathrm{ft}) \ldots \ldots . \ldots 10$

8.0 POST-TEST ACTIONS . . . . . . . . . . . . . . 11

8.1 CONTAINMENT BOUNDARY VERIFICATION $\ldots \ldots \ldots$

8.2 SHIELDING VERIFICATION ........................ 12

8.3 ADMINISTRATIVE ACTIONS $\ldots \ldots \ldots \ldots$

9.0 REFERENCES ........................ 13

10.0 GLOSSARY ............................ 13

APPENDIX A DRAWINGS . . . . . . . . . . . . . . . . . . . . A-1

APPENDIX B OPENING, LOADING, AND CLOSURE PROCEDURE FOR TESTING . . . . B-1

APPENDIX $C$ TEST DATA SHEETS .................... C

\section{LIST OF TABLES}

Table 2-1. Dimensions. ................ . . 3

Table 7-1. Testing Sequence. .............................. 8 
HNF-SD-TP-0TP-004

Revision 0

This page intentionally left blank. 
HNF-SD-TP-OTP-004

Revision 0

\section{TEST PLAN FOR THE M-100 CONTAINER, (MODEL M-101/7A/12/90) DOCKET 96-43-7A, TYPE A CONTAINER}

\subsection{INFORMATION}

The packaging configurations being tested by use of this Test $\mathrm{Pl}$ an are designed and constructed for the U.S. Department of Energy (DOE), Office of Environmental Restoration and Waste Management (EM-43), under the direction of Mr. Stephen Warren. Mr. James D. Greaves, Brainard Associates, Inc., Solon, Ohio, has served as the sponsor's technical point-of-contact for this activity. The packaging is being tested for use by the DOE and its contractors, and according to U.S. Department of Transportation Specification 7A Type A (DOT-7A) requirements. The DOE-approved test facility and personne 1 that will be utilized are located at the Hanford Site in Richland, Washington. Testing is being conducted by Rust Federal Services Inc., Northwest Operations (RFSNW).

The objective of this Test Plan is to describe the testing for the qualification of the M-100 Container, Model M-101/7A/12/90 as a DOT-7A Type A packaging. This packaging system is designed to ship Type A solid, radioactive materials, normal form, Form Number 1, Form Number 2, and Form Number 3 (refer to Section 2.0 of this Test P1an). The nominal, overall external dimensions, including risers, of the M-100 Container, Model M-101/7A/12/90 are $200.66 \mathrm{~cm}$ (length) $\times 137.16 \mathrm{~cm}$ (width) $\times 106.68 \mathrm{~cm}$ (height) [79 in. (length) $\times 54$ in. (width) $\times 42$ in. (height)]. The capacity of the container is $2.55 \mathrm{~m}^{3}\left(89.9 \mathrm{ft}^{3}\right)$. The container weight is estimated to be $435.45 \mathrm{~kg}(960 \mathrm{lb})$. The estimated gross weight of the packaging and contents is $4082.33 \mathrm{~kg}(9000 \mathrm{lb})$. Actual measurements and gross weight for the packaging configurations will be obtained at time of testing.

Refer to Appendix A of this Test Plan for drawings showing information regarding the M-100, Model M-101/7A/12/90 configurations being tested. Two packaging configurations are planned for testing. Each is identical, with the exception that one configuration has risers welded to the underside of the container body, and the other has removable risers. The packaging to be tested is single-piece wall construction, consisting of 12 gauge HR ASTM A569 carbon stee1. The containers are produced using a press-brake method. A NucF $i 1^{1}-013,3 / 4-i n$. NPT filter is located at one end. The containment system includes a $1 / 2 \times 1 / 1 / 2-i n$. Neoprene $e^{2}$ ASTM D-1056 SCE-42 gasket that adheres to the cover by use of Trubond contact cement, Federal Specification MMM-A-130B, or equivalent; and twenty-six 3/8-in. - $16 \times 7 / 8$ hex head cap screws (ANSI B18.2.1, SAE Grade 8), 3/8-in. lock washers (ANSI B18.21.1, SAE Grade 8 ), and $3 / 8$-in. SAE flat washers. The bolt holes are slotted, not drilled. A 3/8-in. chain link lift lug is located at each corner (four

\footnotetext{
${ }^{1}$ NucFil is a trademark of Nuclear Filter Technology, Incorporated.

${ }^{2}$ Neoprene is a trademark of E.I. duPont de Nemours \& Company.
} 
HNF-SD-TP-0TP-004

Revision 0

total). Further information regarding the description of the packagings to be tested is provided in Section 2.0 and Appendix A of this Test Plan.

For testing purposes, the $M-100$, Model $M-101 / 7 \mathrm{~A} / 12 / 90$ will be filled with simulated contents as described in Section 2.0 and Appendix $B$ of this Test Plan. A mixture of flour and fluorescein will be added for ease of any leak detection or simulation of solid, Material Form Number 1 . Visual and ultraviolet light will be used for leak detection.

Test Date:

Docket No:

Packaging Name:

Appl icant Name and Address:

Applicant Phone:

Packaging Manufacturer:

Manufacturer Drawing No.:
June $2-6,1997$

96-43-7A

M-100, Mode1 M-101/7A/12/90

Mr. Stephen Warren

U.S. Department of Energy

Office of Environmental Restoration and Waste Management (EM-43)

Washington, DC 20585

$301-903-7673$

\subsection{PACKAGING DATA}

Jim Greaves

Brainard Associates, Inc.

5381 Brainard Road

Solon, Ohio 44139

216-498-9199

e-mail: ba@en.com

Waste Container Model M-101/7A/12/90, Issue \#4, 1017A-01 through 1017A-08

(Refer to Appendix A of this Test Plan for drawings)

NOTE: At the time this Test Plan was issued for review and approval, the packaging manufacturer had noted that there would be a change to the $1 \mathrm{ift}$ lugs (from $7 / 16-i n$. to $3 / 8-i n$. ), and that the vent filter fitting is part number S-220C not 5-220C. Corrected information and drawings will be provided by the sponsor, and incorporated into this Test Plan via an Engineering Change Notice. 
HNF-SD-TP-0TP-004

Revision 0

Table 2-1. Dimensions.

\begin{tabular}{|c|c|c|c|c|}
\hline \multicolumn{2}{|c|}{ Description } & $\begin{array}{l}\text { Length } \\
\mathrm{cm} \text { (in) }\end{array}$ & $\begin{array}{l}\text { Width } \\
\mathrm{cm} \text { (in) }\end{array}$ & $\begin{array}{l}\text { Height } \\
\mathrm{cm} \text { (in) }\end{array}$ \\
\hline \multicolumn{2}{|c|}{$\begin{array}{l}\text { Outside Dimensions (closed) } \\
\text { with 4-in. risers }\end{array}$} & $\begin{array}{l}200.66 \\
(79.0) \\
\end{array}$ & $\begin{array}{l}137.16 \\
(54.0) \\
\end{array}$ & $\begin{array}{l}106.68 \\
(42.0)\end{array}$ \\
\hline \multicolumn{5}{|c|}{ Interior Volume $=2.55 \mathrm{~m}^{3}\left(89.9 \mathrm{ft}^{3}\right)$} \\
\hline \multirow[t]{2}{*}{ Interna1 Dimensions } & Cover & $\begin{array}{l}193.04 \\
(76.0)\end{array}$ & $\begin{array}{l}129.54 \\
(51.0)\end{array}$ & $\begin{array}{l}5.08 \\
(2.0)\end{array}$ \\
\hline & Body & $\begin{array}{l}193.04 \\
(76.0)\end{array}$ & $\begin{array}{l}129.54 \\
(51.0)\end{array}$ & $\begin{array}{c}90.49 \\
(35.625)\end{array}$ \\
\hline
\end{tabular}

\section{Materials of Construction:}

Container Body, Cover, Risers, \& Stiffeners

Gasket

Gasket Adhesive

Fasteners

Vent Filter

Vent Filter

Fitting

Lift Lug

Weight (estimated):
12 gauge HR ASTM A569 carbon steel.

1/2-in. $x 11 / 2-i n$. Neoprene ASTM D-1056 SCE-42 (Alternate - Ethylene Propylene Diene Monomer [EPDM]).

Trubond contact cement, Federal Specification MMM-A-130B, or equivalent.

Twenty-six, 3/8-in. - $16 \times 7 / 8$ hex head cap screws, ANSI B18.2.1, SAE Grade $8 ; 3 / 8$-in. lock washers, ANSI B18.21.1, SAE Grade 8; and 3/8-in. SAE flat washers.

NucFil-013, 3/4-in. NPT.

2-in. Rieke steel plug with $3 / 4-i n$. opening.

Part No. S-220C.

Chain link, four places. Crosby Spectrum 4, 3/8-in. trade size, or equivalent.

Actual weights for all configurations will be obtained at time of testing.

Gross weight is estimated to be $4082.33 \mathrm{~kg}$ (9000 1b). Approximate weight of empty package is $435.45 \mathrm{~kg}$ (960 1b).

Approximate weight of payload is $3646.88 \mathrm{~kg}$ (8040 1b). 
HNF-SD-TP-0TP-004

Revision 0

Physical Form:

Form Number 1: Solids--any particle size.

Form Number 2: Solids--large particle size only

(e.g., sand, concrete, debris, soil).

Form Number 3: Solids--objects with no significant dispersible or removable contamination.

\section{Simulated Contents:}

The packagings described herein are designed to ship Type A quantities of radioactive materials, normal form, Form No. 1, Form No. 2, and Form No. 3 .

The simulated payload used for testing purposes for all configurations will be six, 208-L (55-gal) drums filled to approximately $453.59 \mathrm{~kg}$ (1000 1b) each. A mixture of sand and soil will fill the void between the drums and the container body. A mixture of approximately 907 grams (2 1b) flour and 85 grams ( $3 \mathrm{oz}$ ) fluorescein will be added to simulate Form No. 1 materials and for leak detection. The flour and fluorescein mixture will be added as necessary for testing purposes (e.g., around the base of the container prior to adding test contents; over the top of the test contents prior to closure; or both). Refer to Appendix B of this Test Plan, Section B6.0, for specific loading of simulated contents per test unit. Care is to be taken so that clumping of the flour and fluorescein mixture will not occur due to the natural moisture that is found in sand/soil.

\subsection{TEST UNIT MARKING}

The test applicant will supply the following:

- One M-100, Mode1 M-101/7A/12/90 container with removable risers.

- Six M-100, Mode1 M-101/7A/12/90 containers with risers welded to the underside of the container base.

- Additional Neoprene gasket material and Trubond adhesive.

Each test unit should be marked in accordance with DOT-7A Type $A$ Packaging Test and Evaluation Procedure, Section 6.3 (Kelly 1996). The components to be marked are the container body and cover. The numbers to be used in marking the test units are listed below. Mark the exterior, assembled surface with four axis lines, $90^{\circ}$ apart. The axis lines shall be 1 abelled $W$, $X, Y$, and $Z$. Orientation angles for drop test locations will be measured from the shortest horizontal centerline axis of the package in its normal upright position. Refer to (Kelly 1996) Sections 1.3 and 6.3 . 
HNF-SD-TP-OTP-004

Revision 0

Marking

43-TU-0I

\section{Configuration}

This test unit has removable risers that are located under the container body. For testing purposes only, this container will contain a typical drum plug, not a NucFil filter. The drum plug is identical to the filter in material and external geometry. Load packaging to the specified testing weight with the selected simulated contents. This test unit will undergo drop testing.

43-TU-02 through 43-TU 07:
These test units have risers welded to the underside of the container body. For testing purposes only, one container will incorporate the NucFil filter; the remaining five containers will contain a typical drum plug. The drum plug is identical to the filter in material and external geometry. Load packaging to the specified testing weight with the selected simulated contents. One of these test units will be empty and will undergo the stacking test. The remaining five test units will be undergo drop testing. The packaging containing the filter will be drop tested.

\subsection{PRE-LOADING INSPECTIONS}

Perform preloading inspections on each test unit in accordance with DOT-7A Type A Packaging Test and Evaluation Procedure, Section 6.4 (Kelly 1996). Record the data on the supplied test data sheets 6.4.1,6.4.2, and 6.4.3 (see Appendix $C$ of this Test Plan). A separate set of data sheets is supplied for each test unit.

Refer to the instructions found in Appendix $B$ of this Test Plan when handling, opening, loading, and closing the M-100 Container.

Perform a visual inspection in accordance with DOT-7A Type A Packaging Test and Evaluation Procedure, Section 6.4.1 (Ke1ly 1996). Visually inspect all surfaces of all units received to ensure that they are in good condition. The visual inspection shall include the following:

\section{Component:}

- Container body and cover - Verify made from 12 gauge (thickness range is 0.1046 in. to 0.0946 in.), carbon steel. Ensure that there are no significant dents that could affect the closure or performance of the packaging. All welds must be continuous--break all sharp edges.

- Gasket sealing surface - Ensure that surface is clean and smooth. 
HNF-SD-TP-0TP-004

Revision 0

- Gasket - Ensure that surface is clean, smooth, and continuous with no rips or tears.

- Bolts and bolt holes - Ensure these are clean and no fouled threads exist.

- Plug and filter - Ensure there are no visible cracks. Ensure installation is to the proper torque according to applicantsupplied instructions.

- Lift lugs - Ensure there are no visible cracks.

Note any deviations from the specifications or drawings; defects in construction, deterioration, deformation; or distortion of features. Record the data on the Packaging Visual Inspection Data Sheet (6.4.1) (see Appendix C of this Test Plan). Use a separate data sheet for each test unit.

After inspection, close the packaging in accordance with instructions found in Appendix B of this Test Plan.

Weigh the major components of all major packaging parts. The major components to be weighed are the container body and cover.

Conduct the weighing in accordance with DOT-7A Type A Packaging Test and Evaluation Procedure, Section 6.4.2 (Kelly 1996). Measure the net weight of the assembled and closed packaging without contents; measure the gross weight of the package loaded with simulated contents. Note the weight of the inspected parts on the Packaging Component Weight Data Sheet (6.4.2) (see Appendix $C$ of this Test Plan). Use a separate data sheet for each test unit.

Measure the exterior and interior dimensions of the container body and cover. Measure the thickness of the gasket material. Note the measurements on the Packaging Component Wall Thickness Data Sheet (6.4.3) (See Appendix C of this Test Plan). Use a separate data sheet for each test unit.

\subsection{SIMULATED PAYLOAD}

The simulated payload to be used is described below. Follow the opening, loading, and closure instructions found in Appendix B of this Test Plan.

43-TU-01:

This test unit has removable risers that are located under the container body. For testing purposes only, this packaging will contain a typical drum plug, not a NucFil filter. Load the packaging to the specified testing weight with the selected simulated contents. Use a mixture of flour and fluorescein for leak detection and Form No. 1 simulation. Refer to Appendix B, Section B6.0 for the 
position of this mixture. This test unit will undergo drop testing.

43-TU-02 through 43-TU-07:

These test units have risers welded to the underside of the container body. For testing purposes only, one packaging will contain the NucFil filter; the remaining five packagings will contain a typical drum plug. Load the packaging to the specified testing weight with the selected simulated contents. Use a mixture of flour and fluorescein for leak detection and Form No. I simulation. The position of this mixture will depend on the feature of the packaging being tested. The position is identified in Appendix B, Section B6.0. One test unit will be an empty packaging used for the stacking test. The remaining five test units will undergo drop testing. The filtered packaging will be drop tested.

\subsection{DESIGN CONFIRMATION SEQUENCE}

\subsection{CONTAINMENT BOUNDARY VERIFICATION}

This is a filtered packaging; therefore, a Reduced Pressure Test will not be conducted. Containment is provided by the container body, lid, gasket, filter, and fasteners (26 hex head cap screws). A visual check for release of simulated contents will be completed prior to each test and after each test.

\subsection{SHIELDING VERIFICATION}

The container body and cover provide shielding. The container body, cover, gasket, filter, and fasteners provide containment of contents. A visual check of the exterior container body and cover will be made prior to each test and after each test. A visual check for release of simulated contents will be completed prior to each test and after each test.

\subsection{TEST SEQUENCE: TEST UNITS 43-TU-01 THROUGH 43-TU-07}

Test units will undergo marking, inspection, and assembly. Due to the materials of construction and design of the packaging configurations being tested, the water spray test will not be conducted as a prerequisite to any other testing. The M-100 containers are made from 12 gauge ASTM A569 carbon steel, include a NucFi1-013 filter, gasket, and 26 hex head cap screws, lock washers, and flat washers. Based on materials and methods of construction, closure mechanisms, gasket, and filter, the water spray would have no effect that could be interpreted as decreasing the ability of the steel boxes to meet all Specification 7A performance criteria. There are years of experience demonstrating that lengthy exposure to rain has no negative effect on containment integrity of similar metal box designs. Based on comparison of similarity in materials and methods of construction of the steel boxes tested 
and evaluated in DOE's Test and Evaluation Document for DOT Specification $7 \mathrm{~A}$ Type A Packaging (DOE/RL-96-57), one can readily conclude that the packaging configurations being tested also meet this requirement.

The penetration bar drop wi11 not be conducted on the M-100 packaging configurations discussed in this Test Plan. By evaluation and comparison (1id, lid reinforcing angle, bolt size, bolt spacing, container flange, filter, and materials of construction) with the performance of the metal boxes and drums previously tested and evaluated in DOE's Test and Evaluation Document for DOT Specification 7A Type A Packaging (DOE/RL-96-57), the materials and methods of construction of the M-100 packaging are equal to or better than those previously tested and evaluated. One can readily conclude that the packaging configurations being tested also meet this performance requirement.

The packages must perform adequately when subjected to the applicable performance tests which are described Table 7-1. There should be evidence that the integrity of the packaging would remain with no release of the hazardous materials to the environment ( 49 CFR 173.24), no loss or dispersal of radioactive contents, and no significant increase the radiation levels recorded or calculated at the external surfaces for the condition before the test [49 CFR $173.412(j)]$.

Each configuration will be considered a unique package for testing purposes. Failure of one configuration does not el iminate the further satisfactory completion of testing for the remaining configurations. In the event of a failed configuration, the test and project engineer, conjunction with the test sponsor, may make an evaluation order to determine whether an alternative internal packaging arrangement may warrant further testing.

Tab7e 7-1. Testing Sequence.

\begin{tabular}{|l|c|c|}
\hline \multicolumn{1}{|c|}{ Type of test } & Reference & Test unit number \\
\hline Stacking test & (Section 7.2) & $43-$ TU-07 \\
\hline Drop test $-1.2 \mathrm{~m}(4 \mathrm{ft}$ ) & (Section 7.3) & $\begin{array}{c}43-\text { TU-01 through } \\
43-T U-06\end{array}$ \\
\hline
\end{tabular}

\subsection{ASSEMBLY, LOADING, AND CLOSURE}

Test No/Event

43-TU-01-1

through

43-TU-07-1

\section{Event/Test Description}

Except where noted, assemble, load, and close the packaging with simulated payload in in position in accordance with Section 5.0 and Appendix B of this Test Plan.

Take pretest photographs. 
HNF-SD-TP-0TP-004

Revision 0

NOTE: Based on evaluation, the packaging design passes the water spray test and suffers no change in strength that would affect the outcome of the other DOT-7A Type A packaging tests. Therefore, as stated in Section 7.0 of this Test Plan, the water spray test will not be conducted prior to any testing described within this Test Plan.

\subsection{STACKING TEST}

Test No/Event

$43-T U-07-3$

\section{Event/Test Description}

For this test, this will be an empty packaging. Assemble and close the packaging in accordance with Appendix B of this Test Plan. An empty packaging is being tested as it is more likely to $f a i l$ than a loaded packaging.

Photograph the pretest condition.

Perform a stacking test in accordance with DOT-7A Type A Packaging Test and Evaluation Procedure, Section 7.3 (Kelly 1996) for at least 24 hours with the compressive load specified below. The load is applied uniformly to two opposite sides of the package, one of which must be the base on which the package would normally stand.

Test Unit Number $\quad$ Compressive Load, $\mathrm{kg}$ (lb)

43-TU-07

$$
20,411.65 \mathrm{~kg}(45,000 \mathrm{~Tb})
$$

\section{Apply 46,000 lb weight}

Calculations were determined as follows:

a) Five times the estimated weight of the package is calculated to be:

$$
5 \times 4082.33 \mathrm{~kg}=20,411.65 \mathrm{~kg} \quad(5 \times 9000 \mathrm{lb}=45,0001 \mathrm{~b})
$$

b) The weight based on the vertically projected area of the package is calculated to be:

$200.66 \mathrm{~cm}$ (length) $\times 137.16 \mathrm{~cm}$ (width) $=27,522.5 \mathrm{~cm}^{2}=2.75225 \mathrm{~m}^{2}$

$2.75225 \mathrm{~m}^{2} \times 1300 \mathrm{~kg} / \mathrm{m}^{2}=3577.925 \mathrm{~kg}$

$$
=(38,512.461 \mathrm{~b})
$$


The compressive load was determined by using the greater of the vertically projected area of the packaging and five times the estimated weight of the package. The load is applied uniformly to two opposite sides of the package, one of which must be the base on which the package would normally stand.

Photograph the package upon the initial test condition setup. Take photographs of the package at the end of the 24-hour test period prior to removing the compressive load and after removal.

After removing the compressive load from the packaging, conduct a visual inspection of the container body, 1id, gasket, fasteners, and risers. If the packaging shows signs of damage, take measurements the same locations as were used for the pretest measurements to document any change. The package will be considered to pass if there is no rupture of or signs of cracks on the container.

Record the results on the Stacking Test Data Sheet (see Appendix $C$ of this Test Plan). Use a separate data sheet for each test unit.

If the package passed the testing conducted in the previous step,

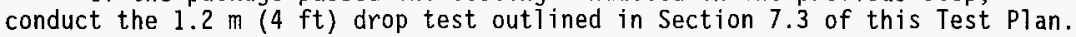

\subsection{DROP TEST $-1.2 \mathrm{~m}(4.0 \mathrm{ft})$}

Test No/Event

43-TU-01-4

$43-T U-02-4$

43-TU-03-4

43-TU-04-4

$43-\mathrm{TU}-05-4$

$43-\mathrm{TU}-06-4$

\section{Event/Test Description}

Assemble, load, and close the packaging with simulated payload position in accordance with Section 5.0 and Appendix B of this Test Plan.

Photograph the pretest condition.

Perform the drop test ${ }^{*}$ in accordance with DOT-7A Type A Packaging Test and Evaluation Procedure, Section 7.5 (Kelly 1996), with the following parameters:

Drop Height: $\quad 1.2 \mathrm{~m}(4.0 \mathrm{ft}),+2.5 \mathrm{~cm}(1.0 \mathrm{in}),-0$.

(use a height of 49 inches)

Impact Angle: See orientation instructions.

"During the drop test, personnel shall be excluded from the impact area to the extent to be clear of any fragments which could result from the impact. As a minimum, this distance shall be $9.1 \mathrm{~m}(30 \mathrm{ft})$. 
Orientation: The orientation angles for the drop test locations will be measured from the shortest horizontal centerline axis of the package in its normal upright position. Refer to (Kelly 1996) Sections 1.3 and 6.3.

43-TU-01 Drop onto bottom short edge, CG

If the test and project engineers determine that the following test unit can undergo a second drop, and upon the agreement of the sponsor, perform the following drop:

43-TU-01 Drop onto bottom corner, CG, on side opposite that of previous drop.

43-TU-02 Drop onto bottom short edge, CG

43-TU-03 Drop onto bottom corner, CG

43-TU-04 Drop onto top corner, CG

43-TU-05 Drop onto top short edge, CG

43-TU-06 Drop flat onto the end to impact the filter

Take photographs and video coverage during and after each test to ensure any damage is photographed.

The packagings will be judged to pass if there is no significant damage to the packagings and no release of contents. Any change from the pretest condition will be evaluated by the test and project engineers to determine if the packaging passed or failed the test and if any additional testing will be necessary.

Record the results on the test data sheets provided in Appendix $C$ of this Test Plan. Use a separate data sheet for each test unit.

If the package passed the testing conducted the previous step, go to Section 8.0 of this Test Plan.

\subsection{POST-TEST ACTIONS}

This process will be performed as noted at the completion of the drop tests as indicated in Section 7.0 of this Test Plan.

\subsection{CONTAINMENT BOUNDARY VERIFICATION}

This is a filtered packaging. The packaging provides containment for solids, Material Form No. 1, Material Form No. 2, and Material Form No. 3. Containment is provided by the container body, lid, gasket, filter, and fasteners (26 hex head cap screws). A visual check for release of simulated contents will be completed prior to each test and after each test. 
HNF-SD-TP-0TP-004

Revision 0

\subsection{SHIELDING VERIFICATION}

The container body and cover provide shielding. The container body, cover, gasket, filter, and fasteners provide containment of contents. A visual check the exterior container body and cover will be made prior to each test and after each test. A visual check for release of simulated contents will be completed prior to each test and after each test.

\subsection{ADMINISTRATIVE ACTIONS}

A written description of the packaging condition and measurements will be thoroughly documented on the appropriate test data sheets after each drop test has been performed. Photographs of damage and video coverage of the tests performed will also be used as documentation.

Perform post-test activities out 1 ined in Section 8.0 of DOT-7A Type $A$ Packaging Test and Evaluation Procedure (Kelly 1996).

Upon test completion, test units shall be marked as follows:

a. Packaging is a test unit belonging to "Brainard Associates, Solon, Ohio."

b. Package testing completed "[enter month/date/year.]"

c. Packaging is an on-hold test unit. Do not return or dispose of without the approval of 7A Testing Support Program Project Engineer, RFSNW.

d. Packaging "does not contain" radioactive material.

e. Packaging "does not contain" hazardous material.

f. Packaging "does not contain" material that requires disposal as a hazardous waste.

g. Packaging surface "does not contain" radioactive contamination.

Refer to TP-D01, Transportation and Packaging Desk Instructions (O'Brien 1992) for guidance on returning test units to the test sponsor. 
HNF-SD-TP-0TP-004

Revision 0

\subsection{REFERENCES}

49 CFR 173, "Shippers - General Requirements for Shipments and Packaging," Code of Federal Regulations, as amended.

49 CFR 178, "Shipping Container Specification," Code of Federal Regulations, as amended.

DOE/RL-96-57, 1996, Test and Evaluation Document for DoT Specification 7A Type A Packaging Rev. 0, Vol. 1, U.S. Department of Energy, Richland Operation Office, Richland, Washington.

Kelly, D. L., 1996, D0T-7A Type A Packaging Test and Evaluation Procedure, WHC-SD-TP-RPT-018, Rev. 1, Westinghouse Hanford Company, Richland, Washington.

O'Brien, J. H., 1992, Transportation and Packaging Desk Instructions, TP-D01, "Return/Disposal of Test Packaging," Rev. 00, Westinghouse Hanford Company, Richland, Washington.

\subsection{GLOSSARY}

\section{ABBREVIATIONS AND ACRONYMS}

$\begin{array}{ll}\text { ANSI } & \text { American National Standards Institute } \\ \text { ASTM } & \text { American Society for Testing and Materials } \\ \text { CFR } & \text { Code of Federal Regulations } \\ \text { CG } & \text { center of gravity } \\ \text { DOE } & \text { U.S. Department of Energy } \\ \text { DOT-7A } & \text { U.S. Department of Transportation, Specification 7A Type A } \\ \text { EPDM } & \text { Ethylene Propylene Diene Monomer } \\ \text { RFSNW } & \text { Rust Federal Services Inc., Northwest Operations }\end{array}$



HNF-SD-TP-0TP-004

Revision 0

APPENDIX A

DRAWINGS

NOTE: At the time this Test Plan was issued for review and approval, the packaging manufacturer had noted that there would be a change to the lift lugs (from 7/16-in. to 3/8-in.), and that the vent filter fitting is part number S-220C not 5-220C. Corrected information and drawings will be provided by the sponsor, and incorporated into this Test Plan via an Engineering Change Notice. 
HNF-SD-TP-0TP-004

Revision 0

This page intentionally left blank. 
NDTE: (UNRESS OTHERWISE NOTED)

CONTAINER SPECIFICATIONS

PACKAGING DESIGNATIDN - 7A TYPE A

MODEL - M-101/7A/12/90

CAPACITY 89.9 CU FT

CONTAINER WEIGHT 960 LBS (THEURETICAL)

PAYLDAD - 8040 LBS

MAXIMUM GRDSS WEIGHT - 9000 LBS

EXTERNAL CUBE W' RISERS - 104 CU FT

EXIERNAL CUBE W/O RISERS - 94 CU FT

STORAGE EFFICIENCY, W/ RISERS - $87 \%$

STORAGE EFFICIENCY WIO RISERS - $96 \%$

DUTSIDE DIMENSIONS -79 IN $X 54$ IN $X 42$ IN, W/ RISERS

STACKING LDAD - 100,000 LBS (NTS RATED)

LIFT LUG WORKING LUAD - 9,000 LBS

MATERIAL - 12 GA HR ASTM AS69 EXCEPT AS NOTED

GASKET - $1 / 2 \times 1-1 / 2$ NEDPRENE ASTM D-1056 SCE - 42

ALTERNATE - ETHYLENE PROPYLENE DIENE MIONOMER (EDPM)

GASKET ADHESIVE - TRUBLND CONTACT CEMENT. FEDERAL SPECIFICATION MMM - A - 130B, DR EQUIVALENT

FASTENERS

$3 / 8$ - $16 \times 7 / 8$ HEX HEAI CAP SCREW, ANSI B18.2.1, SAE GRADE 8

3/8 LOCK WASHER, ANSI B18.21.1. SAE GRADE 8

3/8 SAE FLAT WASHER

VENT FILTER - NUCFIL - 013,3/4 NPT

VENT FILTER FITTING RIEKE P/N 5-2ZOC

TAMPER PROOF SEAL - STRANDED WIRE LEAD SEAL, 2 EACH.

PORTER SAFETY SEAL DR EQUIVALENT

CHAIN LINK - CROSBY SPECTRUM 4 7/16 SIZE

ALTERNATIVE FEATURES

REMDVABLE RISERS

ALTERNATE RISERS

FOKK LIF T COVER LUGS

MANUAL COVER HANDLES

FINISH - AS REQUIRED

MARKINGS - AS REQUIRED

\section{GENERAL NOTES}

ALL EXTERNAL WELDS MUST BE CONTINUDUS AND WATERTIGHT

BREAK ALL SHARP EDGES

THE GASKET SURFACE MUST BE SMOUTH AND CONTINUDUS

CEMENT THE GASKET TO THE CDVER BEFDRE SHIPMENT

ALL FASTENERS MUST BE CERTIFIABLE AS DOMESTICALLY MANUFACTURED

PACKAGE THE FASTENERS AND THE FILTER, AND SUSPEND WITHIN THE

CONTAINER SUCH THAT THEY MAY BE READILY RETRIEVED AT DESTINATIDN

COVER MUST FIT IN BOTH PUSITIONS

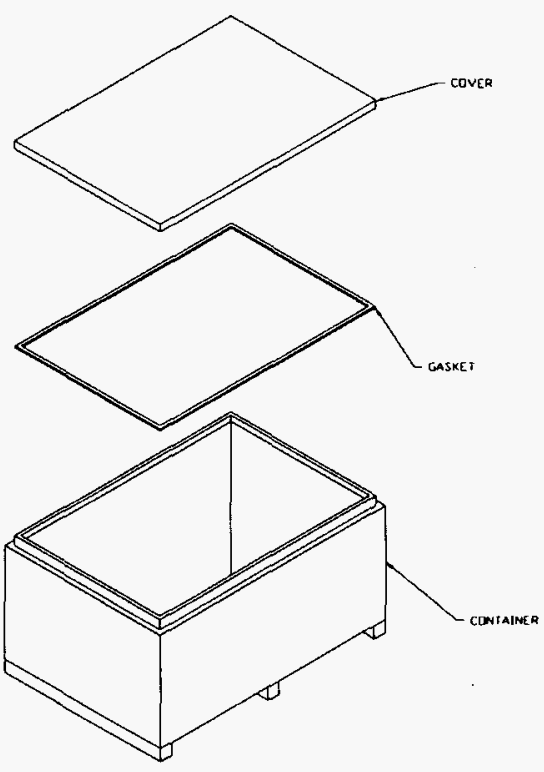

$M-101 / 7 \mathrm{~A} / 12 / 90$ CONTAINER

UNITED STATES

DEPARTMENT OF ENERGY

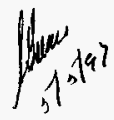

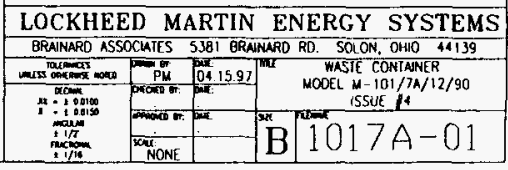




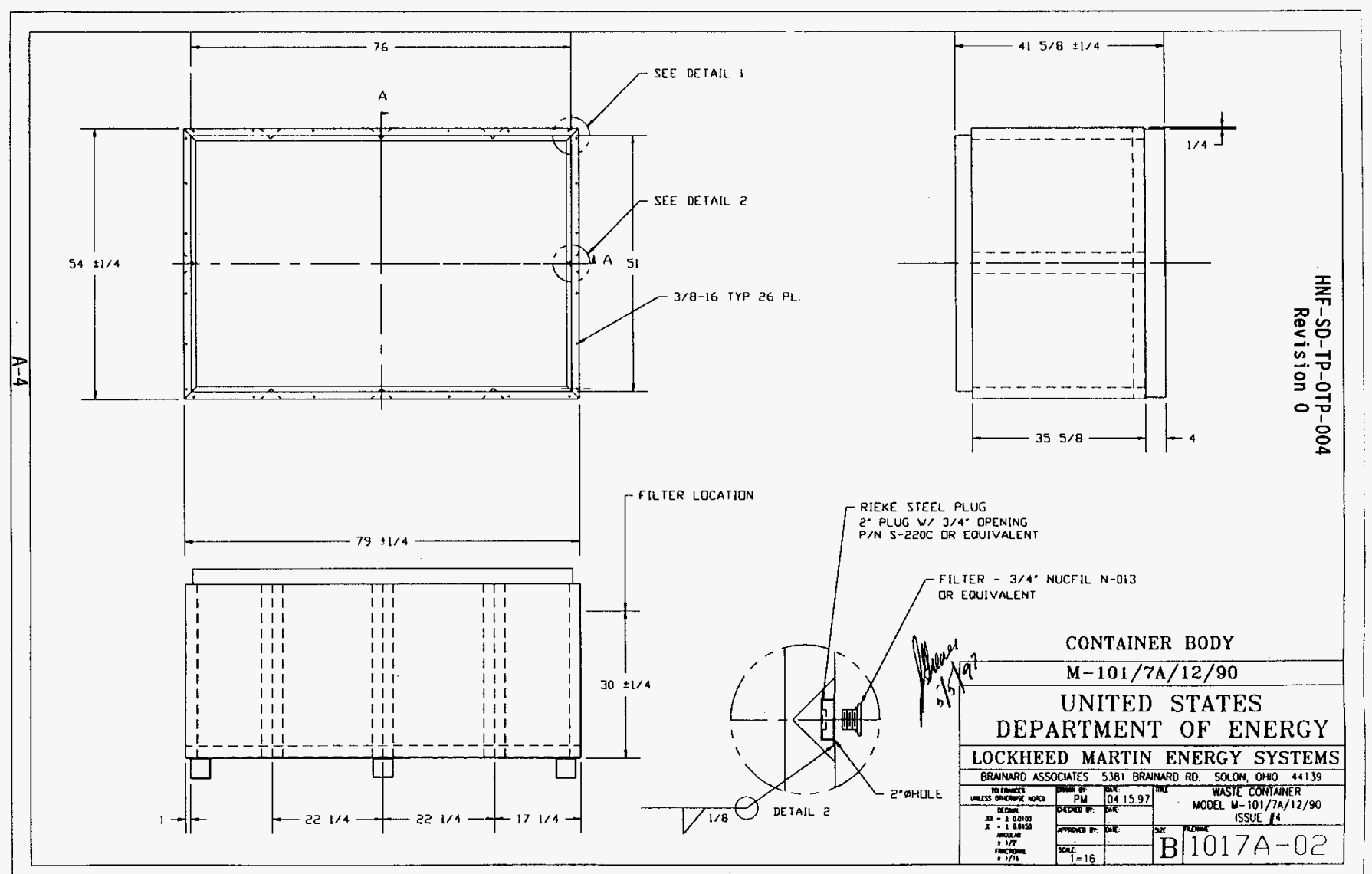




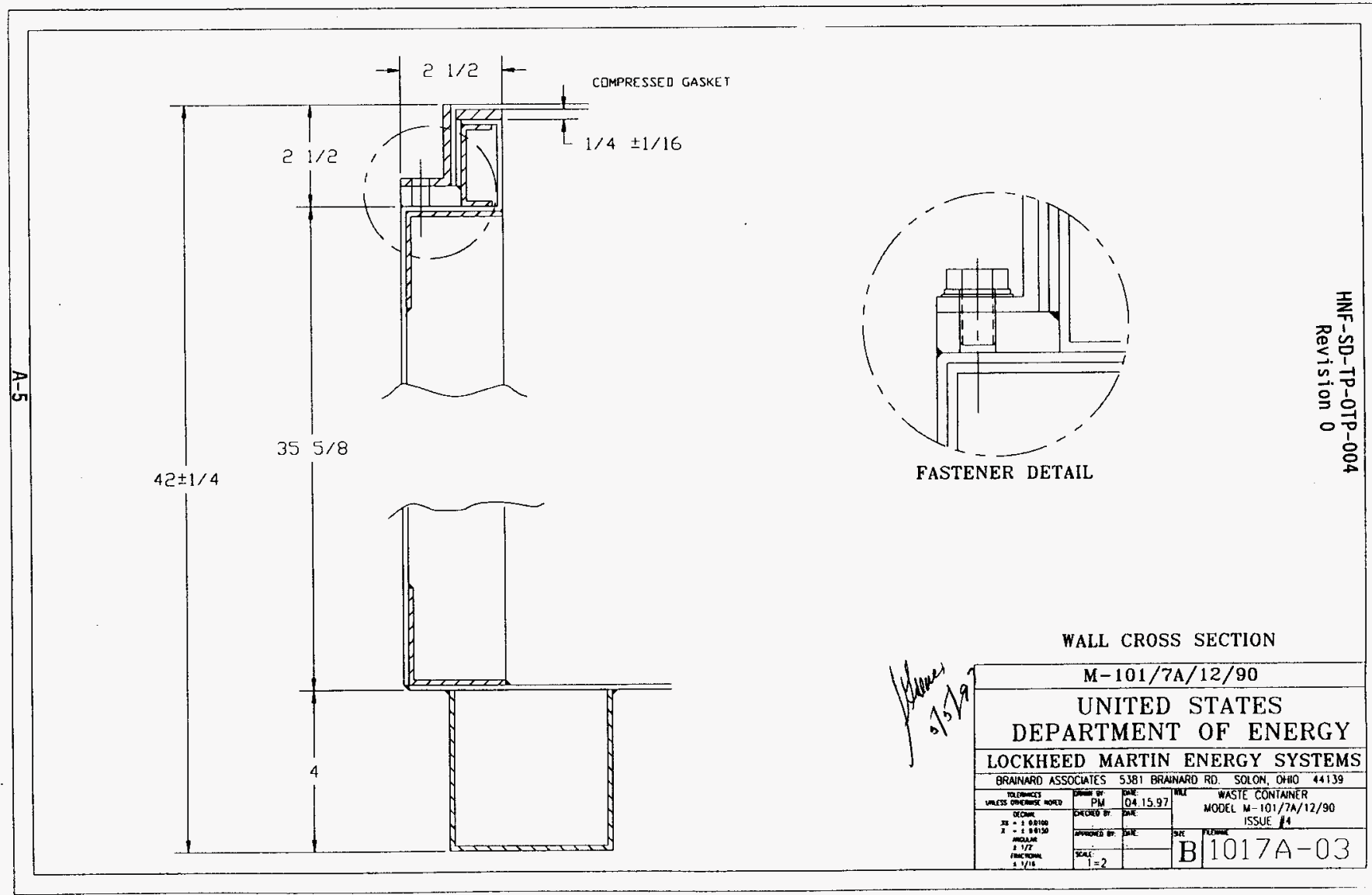


ALL FRACTIONAL DIMENSIDNS SHALL BE W!THIN $\pm 1 / 16$

ALL CUT LENGIHS SHALL BE OC TERMINED AT FABRICATION

LENGTHS SHALL ACCDUNT FOR MATERIAL GAUGE THICKNESS

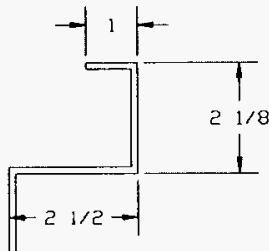

UPPER WALL DETAIL

(1)

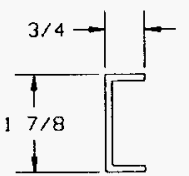

UPPER WALL CHANNEL

(2)

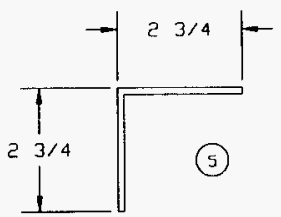

CDRNER STRUT ANGLE

VERTICLE WALL STRUT

UPPER \& LUWER

PERIMETER ANGLES
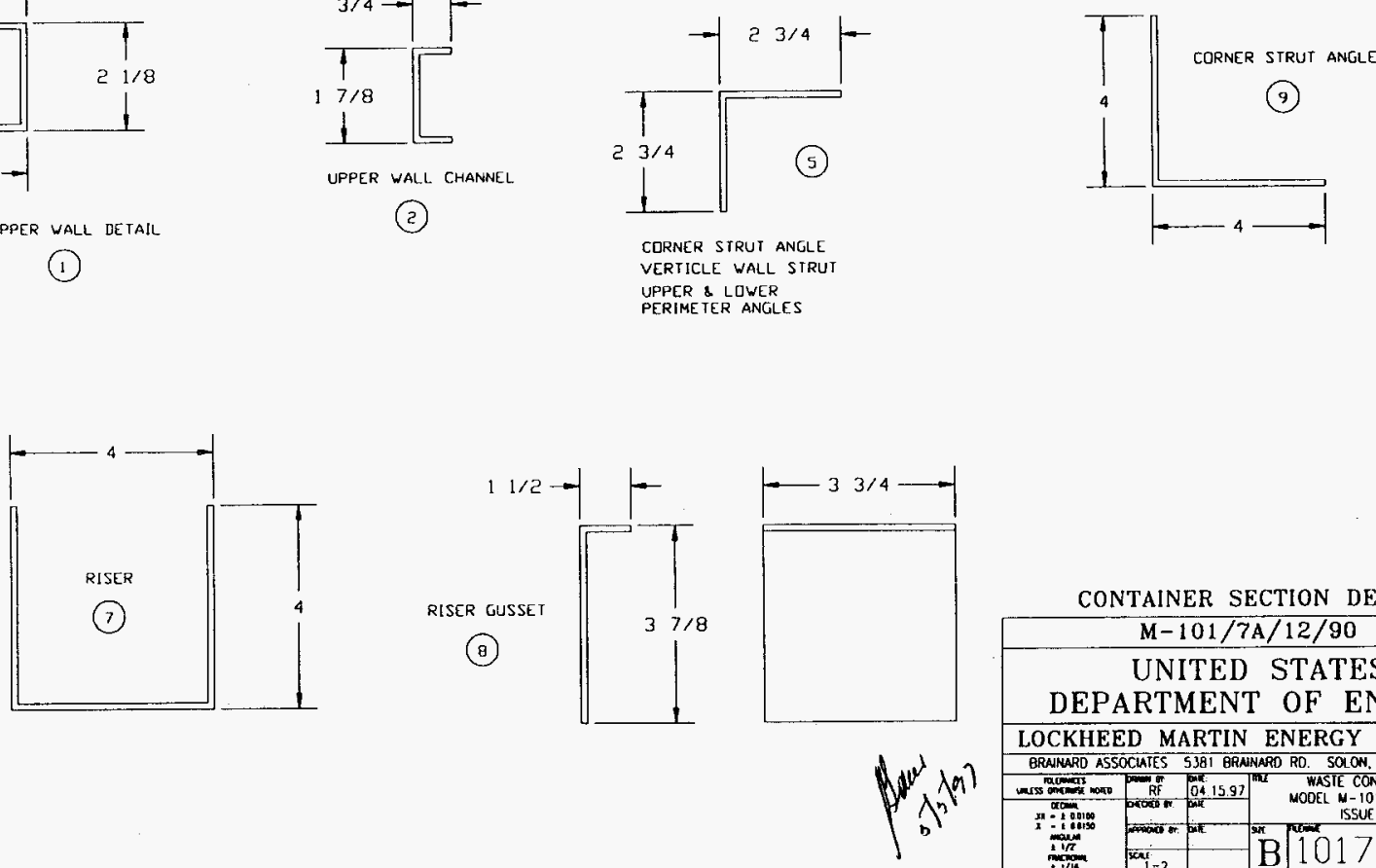

CONTAINER SECTION DETAILS

\begin{tabular}{|c|}
\hline$M-101 / 7 \mathrm{~A} / 12 / 90$ \\
\hline UNITED STATES \\
\hline DEPARTMENT OF ENERGY \\
\hline LOCKHEED MARTIN ENERGY SYSTEMS \\
\hline 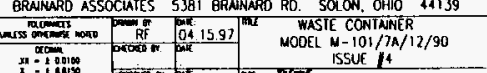 \\
\hline B \\
\hline
\end{tabular}


NOTE

1. MATLL 1/2 X1 I/2 FLAT - A36/M-1020

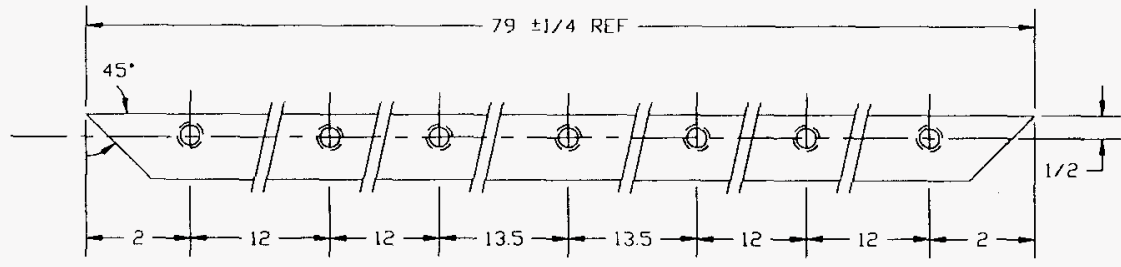

7

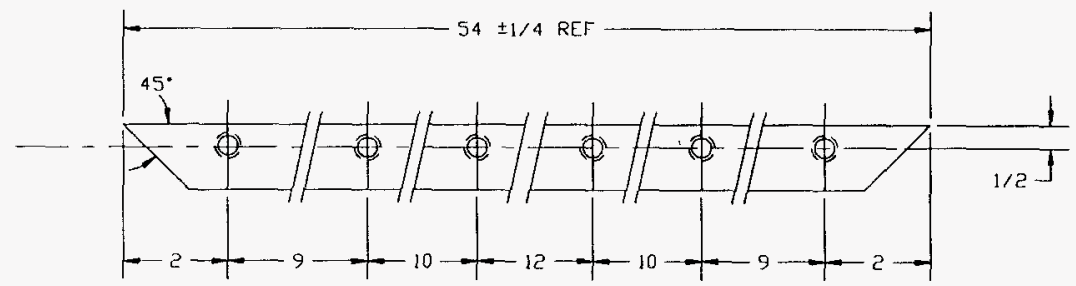

DETAIL ITEM \#4 $M-101 / 7 \mathrm{~A} / 12 / 90$ UNITED STATES

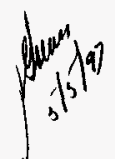
DEPARTMENT OF ENERGY LOCKHEED MARTIN ENERGY SYSTEMS BRAINARO ASSOCIATES 5381 BRNNARO RO. SOLON, OHO 44139

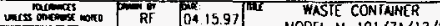

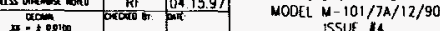




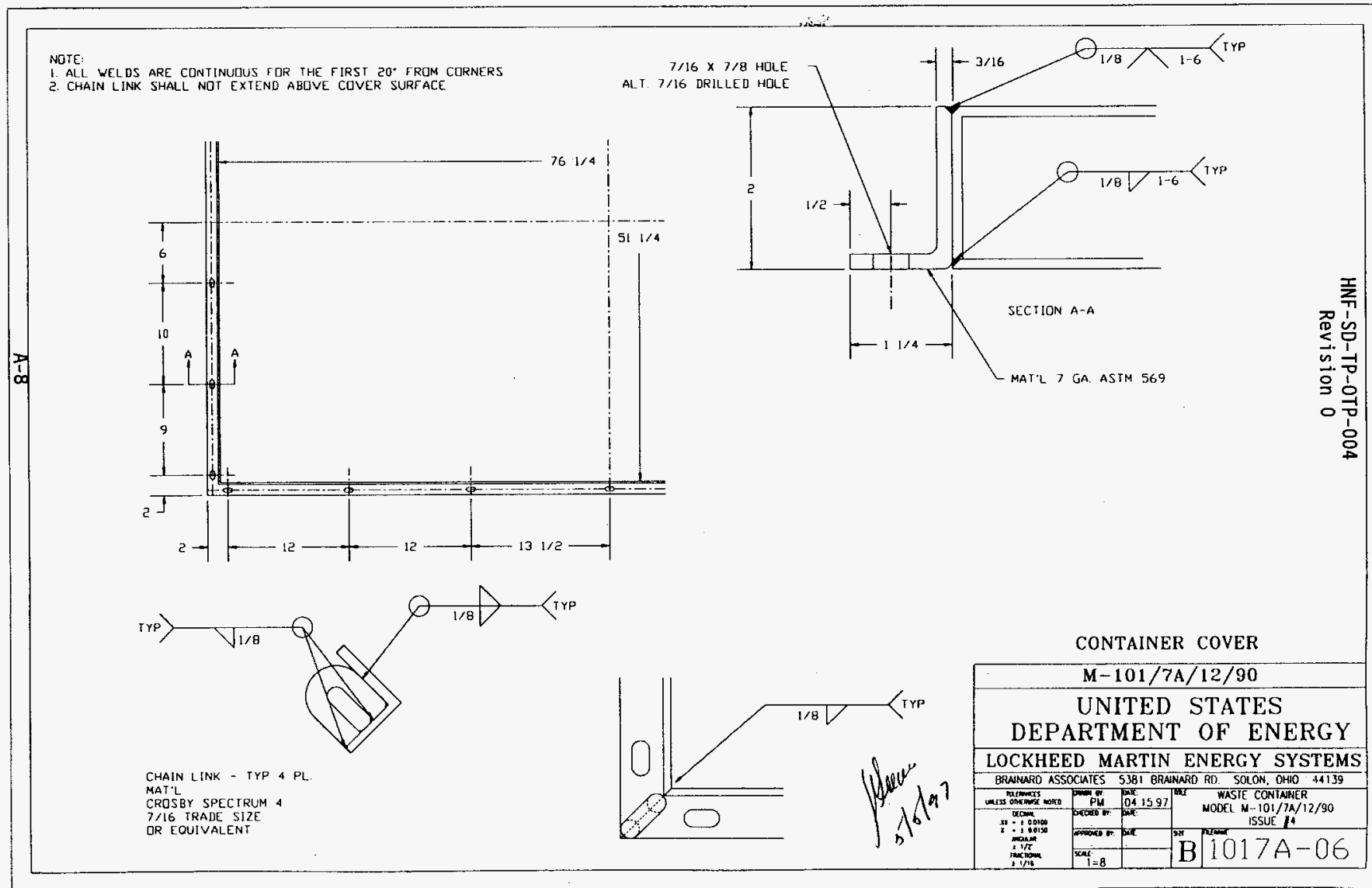


NOTE:

AL CONT NUOUS FDR THE FIRST $20^{\circ}$ IROM CORNERS

2. VERTICAL CORNER STRUT WELDS ARE TO BE

CONTINUAUS FOR THE FIRST $18^{\circ}$ FROM UPPE

CORNERS
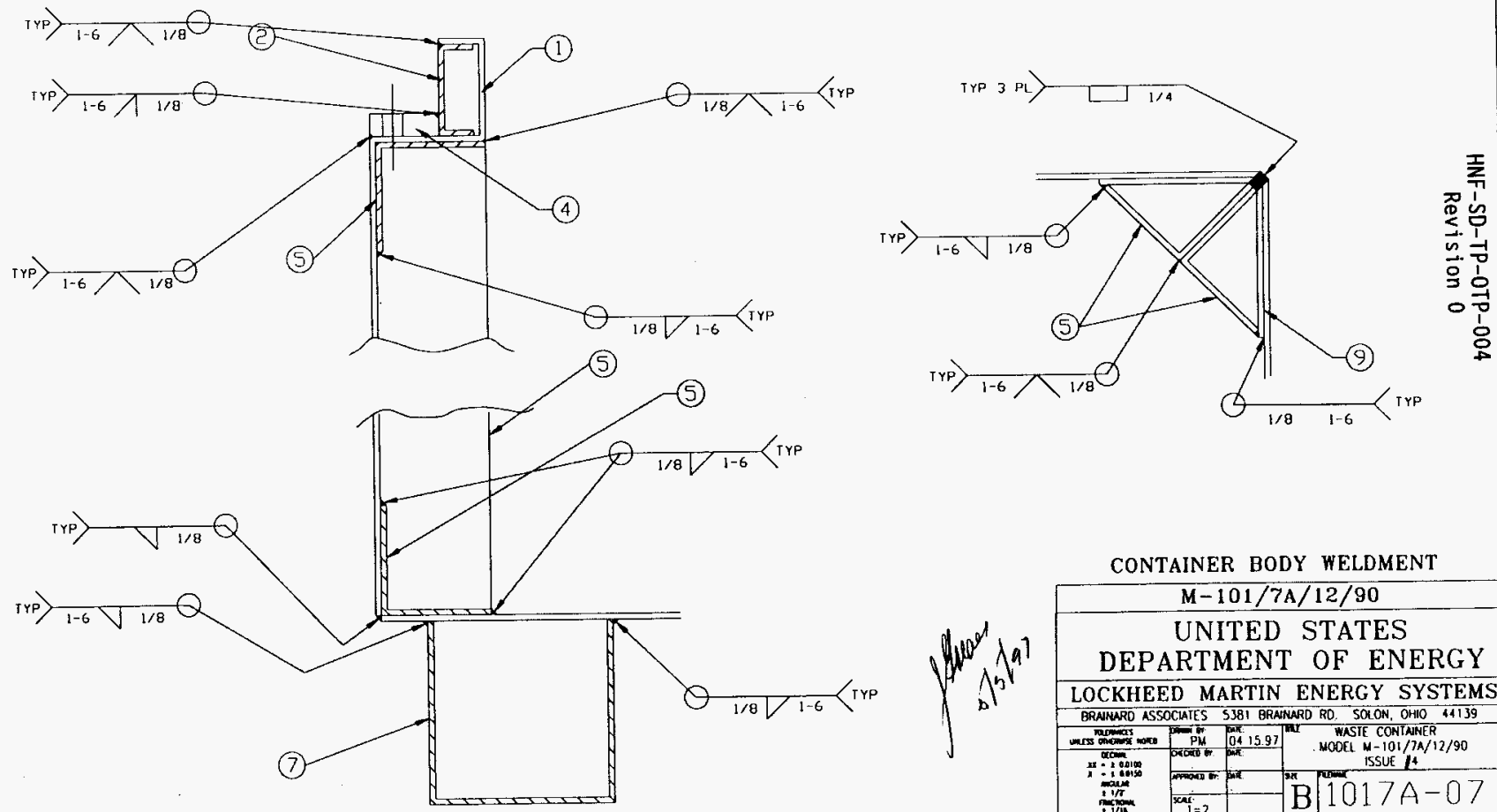

CONTAINER BODY WELDMENT

$M-101 / 7 \mathrm{~A} / 12 / 90$

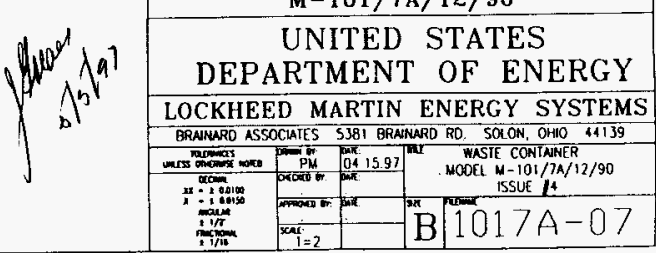




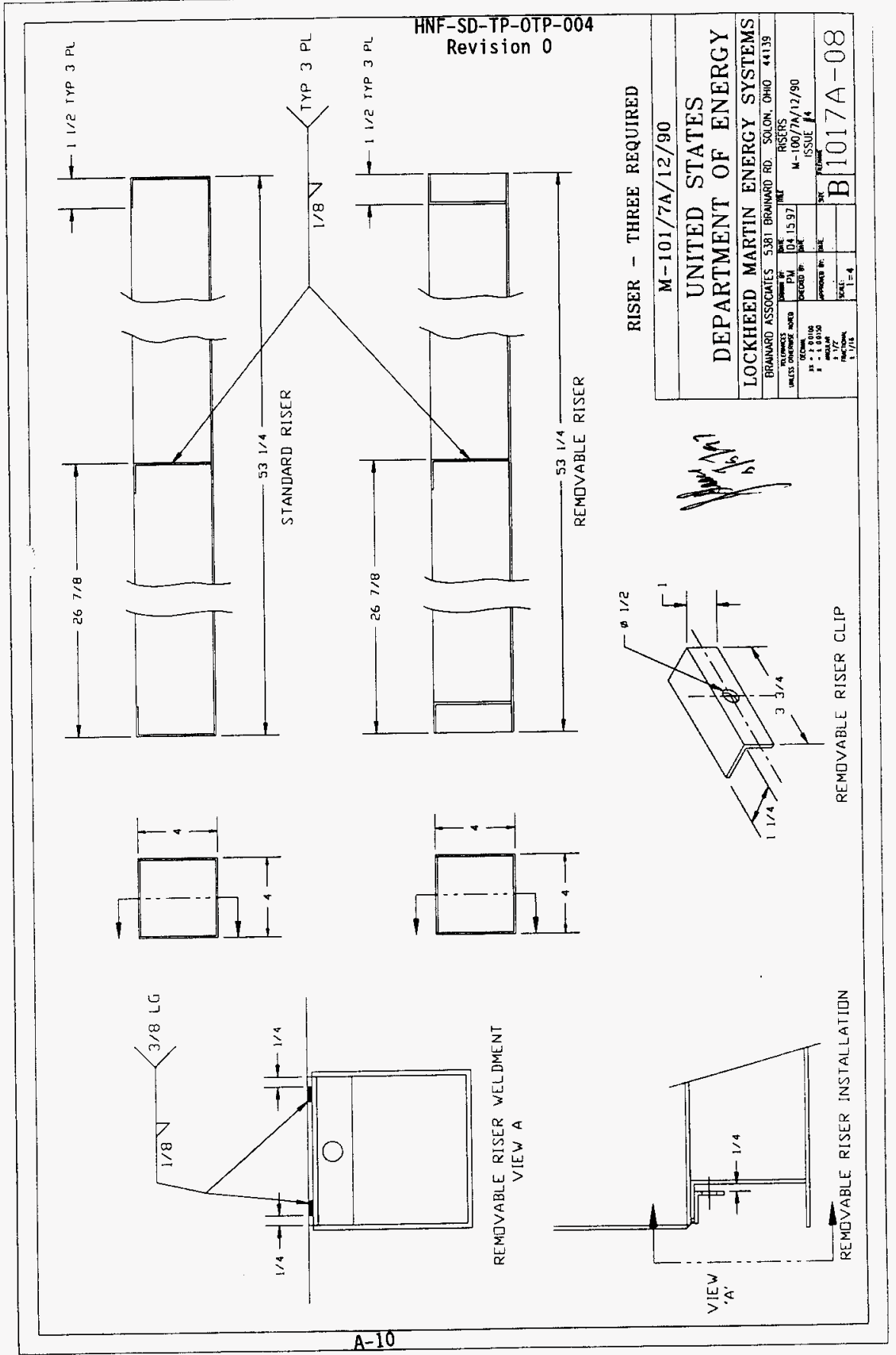


HNF-SD-TP-OTP-004

Revision 0

\section{APPENDIX B}

\section{OPENING, LOADING, AND CLOSURE PROCEDURE FOR TESTING}

The containers will arrive with a system of temporary fasteners securing the cover in place. The temporary fastener system is configured to protect the gasket during shipment. The vent filter, seals, and the cover fasteners will be stowed within the container, arranged for easy retrieval. The container cover will arrive with the gasket cemented in place. Care must be taken not to damage the gasket while handling the cover.

\section{Bl.0 Container Handling}

1. The containers are equipped with three (3) risers to facilitate forklift handling. An alternate system of removable risers is available to facilitate efficient storage at the repository.

2. The containers are equipped with a system of four (4) lifting lugs which permit the overhead lifting of the container by lifting frame or cable slings. Consult site lifting and rigging regulations before overhead lifting.

3. Care must be taken to tighten the lid fastening bolts before overhead lifting.

\section{B2.0 Removal of the Cover}

1. Remove the temporary fasteners using a 9/16-in. socket wrench.

2. Carefully remove the cover so as not to damage the gasket material. The cover may be lifted manually by four individuals.

3. Lay the cover horizontally onto a flat, even surface. If inspection of the gasket material is needed, ensure the cover 1id is gasket-side up (flanges up).

\section{B3.0 Inspection of Gasket Material}

1. Inspect the gasket material to ensure it is smooth and continuous, and that no rips or tears exist.

2. If replacement of the gasket is needed, follow the steps in B4.0. 
HNF-SD-TP-OTP-004

Revision 0

\section{B4.0 Replacement of Gasket Material}

1. Remove the old gasket material completely. Scrape away all adhesive to provide a clean, smooth surface.

2. Square cut the gasket material to exact lengths. Four (4) pieces are required.

3. Remove all loose materials from the bonding surface.

4. Clean the area of the cover where the gasket is to be applied with mineral spirits.

5. Coat the surfaces of the cover where the gasket is to be applied with Trubond contact cement, Federal Specification MMM-A-130B (or equivalent), according to the manufacturer's instructions.

6. Coat the surfaces of the gasket to be butt-joined.

7. Place the gasket in the cover. Care must be taken to position the gasket accurately the first time as bonding will occur upon contact. Any effort to reposition or remove the gasket will result in tearing of the gasket material.

8. As the gasket is laid within the cover, do not pull or stretch the material. Such actions will thin the gasket material and will cause an excess of material beyond the original cut length. Thinning of the gasketing material may have a negative effect upon the performance of the packaging to contain material contents.

9. Assure that the butt-joints are properly positioned and bonded.

\section{B5.0 Installation of NucFil 013 Filter}

1. Clean surface around the threaded filter hole, and assure it is free of dirt.

2. Thread the filter, with its gasket, into the recessed filter fitting located on one end of the container.

3. Tighten the filter to $11 \mathrm{ft}-1 \mathrm{~b}(+2.0 /-0.0)$ with a calibrated wrench. 
HNF-SD-TP-OTP-004

Revision 0

\section{B6.0 Loading the Simulated Contents}

NOTE: One filtered packaging will be provided for testing. The balance of the containers will be fitted with a typical drum plug which is identical to the filter in material and external geometry. Prior to any loading of simulated contents, check the torque level of the plugs that will be in six of the test units. During transportation to the Hanford site, possible loosening may occur. With a calibrated wrench, ensure that the torque level is 11.0 ft-1b $(+2.0 /-0.0)$.

NOTE: Prior to any loading of simulated contents, cover/protect the bolt holes of the container body so that materials do not drop into this space.

NOTE: A mixture of flour and fluorescein will be added to simulate Form No. 1 materials and for leak detection. Care is to be taken so that clumping of the flour and fluorescein mixture will not occur due to the natural moisture that is found in sand/soil. This mixture will be added as follows:

43-TU-07: This test unit has risers welded to the underside of the container body. This test unit will contain a plug, not a filter. This test unit will be an empty packaging, and no simulated contents will be added for testing purposes.

43-TU-01, 43-TU-02, 43-TU-03: Test unit 43-TU-01 has removable risers that are located under the container body. The other two test units have risers welded to the underside of the container body. For testing purposes, these test units will contain plugs, not a filter. These test units will be dropped onto the bottom portion of the container. Add the flour and fluorescein mixture around the bottom of the container at the location where the sidewalls and base intersect. Lay a piece of thin, plastic sheeting loosely on top of this mixture. Continue loading the remaining simulated contents of sand/soil mixture and six drums according to $\mathrm{B} 6 . \mathrm{l}$ below.

43-TU-04, 43-TU-05: These test units have risers welded to the underside of the container body. For testing purposes, these test units will contain plugs, not a filter. These test units will be dropped onto the top portion of the container. Load the six drums into the container and fill the void space surrounding the drums with sand/soil mixture according to B6.1 below. Lay a piece of thin, plastic sheeting on top of the sand/soil. Add the flour and fluorescein mixture near the top edges of the container prior to closure. 
HNF-SD-TP-0TP-004

Revision 0

43-TU-06: This test unit has risers welded to the underside of the container body. For testing purposes, this will be a filtered packaging. This test unit will be dropped on its side at the filter location. Load the six drums into the container and fill some of the void space surrounding the drums with sand/soil mixture according to B6.l below. Be sure to leave the area around the filter free. Place the flour and fluorescein mixture around the filter area. Place a piece of cheesecloth (or other suitable material that will allow air flow around the filter) around the area where the trace material has been added. Continue loading of simulated contents. Lay a piece of thin, plastic sheeting on top of the sand/soil. Add more flour and fluorescein mixture near the top edges of the container prior to closure.

\section{B6.1 Loading Six (6) Drums}

1. Place six (6), 55-gal drums into the container using a drum grapple.

2. Either by the use of a front-end loader or by hand, fill the void space between the container and drums with dirt/sand mixture to the container's rated weight.

\section{B7.0 Closure}

1. Inspect the gasket material per B3.0.

2. Ensure that the gasket surface is free from loose dirt. Care must be taken not to damage the gasket surface.

3. PTace the cover onto the container, gasket-side down. The cover may be lifted manually by four (4) individuals. Care must be taken so as to not damage the gasket surface.

4. The container cover is secured with a system of conventional, highstrength bolts and washers. Two (2) of the bolts are painted red and drilled to receive the stranded wire of the tamper-proof seal. These bolts are to be placed at diagonal corners of the container, in a hole adjacent to the lifting lug.

5. Place a lock washer, then flat washer onto a bolt. Thread the bolt into a tapped hole in the container body until finger tight. Repeat the process at each bolt hole.

6. Starting at a corner, alternate holes (every-other-one) until all bolts are in place. Remember to place the red-painted bolts at diagonal corners of the container, in a hole adjacent to the lifting lug. 
HNF-SD-TP-0TP-004

Revision 0

The following pattern will be used during testing:

$\begin{array}{ccccccc}1 & 14 & 2 & 15 & 3 & 16 & 4 \\ 26 & & & & & & 17 \\ 13 & & & & & & 5 \\ 25 & & & & & & 18 \\ 12 & & & & & & 6 \\ 24 & & & & & & 19 \\ 11 & & & & & & 7 \\ 23 & 10 & 22 & 9 & 21 & 8 & 20\end{array}$

7. Torque the bolts to 450 in-1b $( \pm 10 \%)$, using a calibrated wrench.

8. The tamper-proof wire will not be added during testing. 
HNF-SD-TP-0TP-004

Revision 0

This page intentionally left blank. 
Brainard Associates, lnc.

Low-level Waste Contuiner Specialists

\$381 Brainard Road, Solon, Ohio 191310

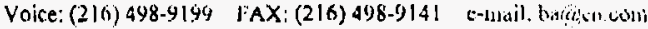

\section{CONTAINER OPERATING INSTRUCTIONS \\ $\mathrm{M}-101 / 7 \mathrm{~A} / 12 / 90$ \\ ISSUE 4 KeV. I}

\section{LOADING - (6) DRUM paylond}

- Place six (6) 55 gallon drums in the container using a drum grnpple.

- Care must be taken not to exced the contulner's ialeal welght.

- Clean the gasketing surface uistil it is frec from loisc dirt.

- Care must be taken not to damage the gasketlang surfince.

\section{LOADING - LOOSE MATERIALS, ANY PAKIICULAIE SIZE}

- Either by the use of a front end loader or by hand, load the container with materials to the container's rated wolght.

- Clean the gasketing surface until it is free from louse dirt.

- Care must be taken not to danage the gasketing sur fnce.

- The container will arrive with a system of temporary fastencrs secur lug the curcr in place. The temporary fastener system is configured to protect lipe gasket during shipment. The vent filter (as required), the seals, and the cover fasteners will be stowed within the container, arranged for easy retrieval. 'The contaluer cover will arrive with the gasket cemented in place. Care unust he taken not to damuge the gustict while handling the cover. In the event the gasket must be replased in the ficld, the following Instruetions should be followed.

- Lay the cover hurizontally, nanges up.

- Remove the old gasket material completcly. Scrape away all adhesive to provide n clenn smooth surface.

- Square cut the gasket matcrial to exact lengths, fuur (4) pleces are requlicd.

- Remove all loosc materlals frum the bonding surfucc

- Clean the cover gaskel arca with inlineral splitis.

- Coat the surfaces to be bonded according to the manufacturers instiuctions.

- Coat the surfaces of the gasket tu be butt-joined.

- Place the gasket in the cover. Care must be taken tu positlon the gaslact

- accurately the first time. It will bond immediately upon cuntact. Any cffurt to, reposition or remove the gasket will result in tearing the gasket materinl.

- Assure that the butt joints are properly positioned and bonded

- As the gasket is laid within the cover do not pull or stretch the matcrial. Such aclions will thin the material and will cause an execss of matestal beyond flie arkginal cul Ienglh. 


\section{CONTAINEK HANDLING;}

- The M-100 containers are equipped with three (3) fixed risers to facilitate fork lifi handling, and a system of four (4) lifting lugs which permit the overhead lifung of the contalner by lifting frame or cable slings. Care inust be taken to tighten the jid fastening bolts before overhead lifing. Consult site lifing and rigging regulations before overhead tifting.

- An alternate system of removable risers is available to faclitate efricient storage at the repusflury,

\section{CLOSURK}

- The container cover is secured with a system of conventional high strength bolts and washers. Two (2) of the bolts are painted red and drilled to receive the stranded wirc of the tamper prouf seal. These bolis are to be placed at diagonal corners of the contailler, in a hole adjaccnt to the Iffting lug.

- Place the cover upon the container, taking care not to disturb the gasket.

- Thrcad a bolt with its washer and lock washer in place into each of the holus. Srarting at the corner, alternate holes(cyery other onc) until all bolts are in place.

- Torque the bolts to $450(+1-10 \%)$ in, Lb.

- Thread the stranded wire through the drilled bolt head and the cover lifting lug ano secure the lead seal. Repeat the process at the dlagonal corner

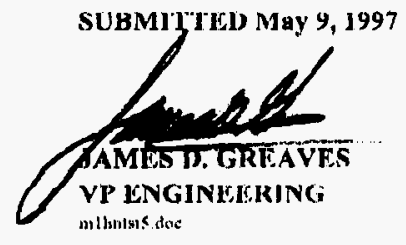


HNF-SD-TP-0TP-004

Revision 0

APPENDIX C

TEST DATA SHEETS

NOTE: TEST DATA SHEETS WILL BE INCORPORATED INTO THIS TEST PLAN VIA AN ENGINEERING CHANGE NOTICE ONCE TESTING IS COMPLETED AND INFORMATION IS

OBTAINED. 
HNF-SD-TP-OTP-004

Revision 0

This page intentionally left blank. 